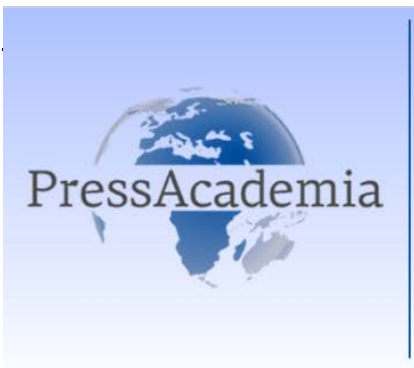

Press Academia Procedía

Global Business Research Congress (GBRC), May 26-27, 2016, Istanbul, Turkey.

\title{
THE NEGATIVE FACTORS AFFECTING THE BORDER TRADE IN EASTERN AND SOUTHEASTERN ANATOLIA AND ECONOMIC IMPACTS
}

DOI: 10.17261/Pressacademia.2016118674

Mehmet Dag ${ }^{1}$, Burak Okde ${ }^{2}$

${ }^{1}$ Hakkari Üniversitesi mehmetdag@hakkari.edu.tr

${ }^{2}$ Hakkari Üniversitesi burakokde@hakkari.edu.tr

\begin{abstract}
Limits in some areas of the world is losing its former importance in recent years, it is becoming more and more important to win and in need of protection in some areas. In particular, the development between countries and regions, income distribution and inequality deepened in areas where border trade and border control are gaining more importance. In places where natural border illegally providing security incidents are increasing and that national interests can be damaged significantly. In our country, especially in the eastern region, which is very difficult at the border village of inspection and control of border smuggling, can be observed is not considered an illegal activity as a social perspective. The aim of the East and the size of the actual border smuggling trade in the Southeastern Anatolia Region, is to understand the types and causes. The smuggling is carried out in the framework of this species and caused economic losses by providing data on the size of this data will be made through evaluations of policy recommendations will be developed.
\end{abstract}

Keywords: Foreign trade, economics, accounting and auditing

JEL Codes: F31, A10, H83

\section{DOĞU VE GÜNEYDOĞU ANADOLU BÖLGELERINDE SINIR TICARETINI OLUMSUZ ETKILEYEN FAKTÖRLER VE EKONOMIK ETKILERi*}

\section{ÖZET}

Son yıllarda dünyanın bazı alanlarında sınırlar eski önemini yitirirken, bazı alanlarda daha fazla önem kazanmaya ve korunmaya muhtaç hale gelmektedir. Özellikle, ülkeler ve bölgeler arasındaki gelişmişlik, gelir dağılımı ve eşitsizliğin derinleştiği yerlerde sınır ticareti ve sınırların kontrolü daha fazla önem kazanmaktadır. Sınır güvenliğinin sağlanamadığı yerlerde doğal olarak illegal olaylar artmakta ve ulusal çıkarlar bundan ciddi ölçüde zarar görebilmektedir. Ülkemizde ise özellikle doğu bölgelerinde, sınır köylerinde kontrolü ve denetimi çok zor olan sınır kaçakçılığının, sosyal bakış açısı olarak kanuna aykırı bir faaliyet olarak değerlendirilmediği gözlemlenebilmektedir. Bu çalışmanın amacı Doğu ve Güneydoğu Anadolu Bölgelerinde gerçekleşen sınır ticaretinin kaçakçılığının boyutlarını, türlerini ve nedenlerini anlamaya çalışmaktır. Bu çerçeve bölgede gerçekleştirilen kaçakçılık faaliyetlerinin türleri ve neden olduğu ekonomik kaybın boyutu hakkında veriler temin edilerek bu veriler üzerinden yapılacak değerlendirmeler sonucunda politika önerileri geliştirilecektir.

Anahtar Kelimeler: Dış ticaret, ekonomi, muhasebe ve denetim

JEL Kodları: F31, A10, H83

\footnotetext{
Bu çalışma Hakkari Üniversitesi Bilimsel Araştırma Projeleri Koordinatörlüğü tarafından IIBF2015BAP1 kodlu proje kapsamında desteklenmiştir.
} 


\section{GiRiş}

Sınır aşan suçlar, bugün dünyanın karşı karşıya kaldığı en önemli sorunlardan birisidir. Son yıllarda dünyanın bazı alanlarında sınırlar eski önemini yitirirken ( Avrupa Birliği'nin iç sınırlarında olduğu gibi), bazı alanlarda daha fazla önem kazanmaya ve korunmaya muhtaç hale gelmektedir. Özellikle, ülkeler ve bölgeler arasındaki gelişmişlik, gelir dağılımı ve eşitsizliğin derinleştiği yerlerde sınırların kontrolü daha fazla önem kazanmaktadır. Sınır güvenliğinin sağlanamadığı yerlerde doğal olarak illegal olaylar artmakta ve ulusal çıkarlar bundan ciddi ölçüde zarar görebilmektedir (Deniz, 2011).

Nedenleri ve sonuçları olarak çok karmaşık bir kavram olan kaçakçılık, ekonomik ve vergisel nedenlere dayandığı kadar sosyal, siyasi ve toplumsal nedenlere de dayanmaktadır. Özellikle, doğu bölgelerinde, sınır köylerinde kontrolü ve denetimi çok zor olan sınır kaçakçılığının, sosyal bakış açısı olarak kanuna aykırı bir faaliyet olarak değerlendirilmediği gözlemlenebilmektedir. Sınırın iki yanında çoğu zaman aynı aileye mensup kişiler tarafından yürütülen kaçakçılık faaliyetleri ticaret olarak görülebilmektedir. Bu durumu engellemeye çalışan devlet ise, eğitim ve bilinç seviyesi düşük durumda olan vatandaşlar tarafından bir baskı unsuru ve ticaretlerine engel olan bir otorite olarak algılanabilmektedir. Bu durum vergi kaybına neden olduğu gibi, devlete karşı da bir tepki doğmasına neden olabilmektedir.

\section{VERGI KAVRAMI}

Kamu giderlerinin finansmanında başvurulan kaynakların en önemlisi olan verginin kökeni, toplum halinde yaşamanın ve devlet bilincinin gelişmeye başladığı dönemlere kadar uzanmaktadır. Vergiler başlangıçta tamamen mali amaçlarla kamu harcamalarıı finanse etmek için alınırken özellikle 19. yüzyılın ikinci yarısından itibaren ekonomik ve sosyal amaçlar için de kullanılmaya başlanmıştır. Bu durum hem vergilere verilen önemi arttırmış hem de yükümlülerle devletin daha sıkı bir etkileşim içine girmesini sağlamıştır (Çiçek, 2006).

Vergi, kaynağı milli gelir olup devletin, kamu harcamalarını karşılamak üzere kişilerden egemenlik gücüne dayanarak ve kişilerin ödeme güçlerine göre tek taraflı, nihai ve zorunlu olarak aldığı paralardır (Eker, 2001:119). Devletin otoritesine dayanarak cebri olarak topladığı vergiler zaman zaman yüksek oranlarda toplanabilmektedir. Bu durumda mükellefler vergi oranlarının yüksekliğinden, kamu hizmetlerinden yeterince yararlanmadıklarını düşündüklerinden veya vergi bilincine sahip olmadıklarından dolayı vergi ödemede istekli davranmayabilirler. Gerekli denetimlerin ve cezaların da yetersiz kaldığı böyle durumlarda vergi kaçırma, vergilendirilmemiş ürünlerin ülkeye kaçak yollardan sokulması yoluyla devletin bu ürünlerden elde edeceği vergiden mahrum kalması gibi durumlar "vergi dışı piyasa ekonomisi"ne neden olmaktadır.

Böyle durumlarda piyasa ekonomisinde verginin konusunu oluşturan iktisadi faaliyet ve işlemlerden devletin her zaman vergi alabilmesi mümkün olamamaktadır. Kimi zaman, vergiye tabi iktisadi faaliyetlerden elde edilen gelir, vergi idaresinin tamamen bilgisi dışında kalmakta, bazen de elde edilen gelirin sadece beyan edilen bir kısmı vergilendirilebilmektedir. Aynı şekilde verginin konusunu oluşturan servetten (taşınır ve taşınmaz mülkiyet vs.), bu servetin kiraya verilmesi dolayısıyla elde edilen gelirden (irat), servetin karşılıklı ya da karşııksız transferinden ya da servetin belirli bir zaman diliminde değer kazanmasından elde edilen kazançtan her zaman tam ve eksiksiz vergi alındığı söylenemez. Bunun yanı sıra, piyasa ekonomisinde mal ve hizmetlerin üretimi, satışı ve tüketimi de verginin konusunu oluşturabilir ve bu işlemler tam ve doğru bir şekilde vergilendirilmeyebilir. İște "vergi dışı piyasa ekonomisi", tüm bu belirtilen ve verginin konusunu oluşturan, fakat çeşitli nedenlerle vergilendirilemeyen işlem ve faaliyetleri ifade eden bir kavramdır (Aktan, 2006:189).

Kamu harcamalarının büyük kısmının karşılandığı ve en büyük gelir kaynağı olan vergi gelirleri, devletler açısından taşıdığı bu önemden dolayı devletler de bu konuda tedbirlerini almaya çalışmaktadır. Denetimlerle ve cezai müeyyidelerle önüne geçilmeye çalışılan vergi kaçakçılığı ve kaçak yollarla ülkeye ürün sokulması faaliyetlerinin yeterince önlenemediği söylenebilir. Bu durumda devletler, denetim ve cezai müeyyidelerin yanında, mükelleflerin vergi verme arzusunu arttırmayı ve vergi bilinci oluşturarak insanların vergi vermede gönüllü olmasını hedefleyerek vergi gelirlerindeki azalmayı önlemeye çalışmaktadırlar.

Özellikle son 15-20 yıldan beri başta ABD olmak üzere Hollanda, İspanya, İsviçre ve Danimarka gibi ülkeler vergi verme davranışı üzerindeki mükellef tutumlarına ciddi bir şekilde eğilmektedir. Bu amaçla söz konusu ülkelerde 
vergi mükelleflerinin "kendi rızaları" ile vergi ödeme istekliliklerini artıran faktörlerin neler olduğu saptanmakta ve daha sonra da bu faktörlerin vergi mükelleflerinin gelirlerini doğru beyan etmelerine olan etkisi ampirik ve deneysel çalışmalarla test edilmektedir (Andreoni vd. , 1998).

Vergi kayıp kaçaklarını engellemeye yönelik tüm bu çalışmalara rağmen devletlerin bu konuda tamamen başarıya ulaştığını söylemek kolay olmayabilir. Gerek mükelleflerin vergi ödeme isteksizliği, gerek ülke sınırlarından ülkeye kaçak yollardan sokulan kayıt dışı ürünlerin yarattığı vergi kaybı, ekonomik sorunlara neden olabildiği kadar, sosyal yönden de devletler açısından olumsuz etkilere neden olabilmektedir.

\section{KAÇAKÇILIK FAALIYETLERINE NEDEN OLAN ETMENLER}

Kaçakçılık faaliyetleri konusunda ve kaçakçılık olgusunda incelendiği zaman görülmektedir ki, üzerinde birleşilmiş net bir tanım yapılamamaktadır. Özellikle, devletin en önemli gelirini oluşturan vergi gelirleri üzerinde olumsuz etki oluşturmasına rağmen bu konuda bir fikir birliği sağlandığı söylenememektedir. Kaçakçılık faaliyetinin tanımı şu şekilde yapılabilmektedir; ürünün illegal yollarla ülkeye sokulması veya ülkeden çıkarılması suretiyle devletin zarara uğratılmasına neden olan eylemdir.

Dünya Gümrük Örgütünün yaptığı tanıma bakacak olursak;

-Ticari eşya sevkiyatı üzerindeki vergi, resim ve harçları ödemeden kaçınmak veya buna teşebbüs etmek,

-Ticari eşya için uygulanmakta olan yasaklama, sınırlama ve kısıtlamalardan kaçınmak veya buna teşebbüs etmek,

-Herhangi bir vergi iadesi, sübvansiyon veya ödemeyi haksız yere almak veya buna teşebbüs etmek,

-Iş hayatında meşru rekabet ilke ve uygulamalarını zedeleyici haksız ticari avantaj elde etmek veya buna teşebbüs etmek, Amacıyla gümrüklerin uygulanmasından sorumlu olduğu kural koyucu ve düzenleyici mevzuat hükümlerinin herhangi bir şekilde ihlali olarak tanımlanmıştır (Yaşar, 2012).

Gerek ulusal düzeyde, gerek uluslararası mevzuatta ortak bir tanım üzerinde fikir birliği sağlanmasa da, kaçakçılık eylemlerinin bir suç olduğu üzerinde fikir birliğinin sağlandı̆̆ı görülebilmektedir. Devletler bu suç ile mücadele etmekte, kaçakçılık faaliyetine konu olan mallara yakalandığı takdirde el koymaktadır. Ayrıca, kaçakçılık faaliyetini yürütmeye çalışan kişi veya gruplar da, bu denetim ve cezai işlemlerden kaçabilmek için, tehlikeli yöntemlere başvurarak hayatlarını riske atmakta ve hayatlarını kaybedebilmektedirler. Bütün bu engelleyici koşullara rağmen, kaçakçılık faaliyetlerinin sonlanmadığı ve halen devam ettiği görülebilmektedir. Bu durum ise kaçakçılık faaliyetlerinin altında yatan motivasyonu ve kaçakçının neden bu riskleri göze aldığını sorgulatabilmektedir.

\subsection{Vergi Oranları ve Vergi Yükü}

Vergi oranlarının ve vergi yükünün yüksekliği kaçakçılık faaliyetleri ile yakın bir ilişki içinde olduğu söylenebilir. Çünkü, kaçakçılık faaliyetlerinin altında yatan temel neden, fiyat farklılıklarıdır. Kaçakçılığı besleyen bu fiyat farklılıkları, ürünün kaçak yollarla, ucuz olduğu bölgeden pahalı olduğu bölgeye transfer edilmesine neden olur. Bir sınırın iki farklı bölgesinde bir ürünün riskli şekillerde kaçakçılığa konu olabilmesi için bu fiyat farkının yüksek olması gerektiği söylenebilir. Bu fiyat farklııklarının oluşmasında en büyük etmenlerden biri, ürünlerden alınan vergilerin ürün fiyatını yükseltebilmesidir.

Ülkemiz için kaçakçılık faaliyetlerine en çok konu olan ürünlerden birisi akaryakıt ürünleri olduğu gözlemlenebilmektedir. Ülkemizde akaryakıtın diğer komşu ülkelerden daha pahalı olması, özellikle petrol zengini ülkelerle komşu olmamızdan dolayı akaryakıt kaçakçılı̆ını cazip hale getirmektedir.

Türkiye ile İran arasında akaryakıt ürünlerinin alım satımında ortaya çıkan büyük fiyat farkının kaçakçılığı cazip hale getirmektedir. Türkiye ve İran dünyanın en pahalı ve en ucuz akaryakıtını kullanan iki komşu ülkedir. Türkiye-İran sınırındaki akaryakıt kaçakçılığının temel nedeni de bu fiyat farkıdır (Deniz, 2011). İki ülke arasında bu kadar fiyat farklılığının olmasının en büyük nedeni ise Türkiye'de akaryakıt ürünlerinden alınan verginin yüksek olmasıdır. 
Vergi oranlarının ekonomik faaliyetlere olan etkisi teorik çapta birçok çalışmayla kanıtlanmıstır. Ancak bunlar içerisinde en çok bilineni Arthur Laffer tarafından ortaya konulan ve arz yönlü iktisadın en önemli dayanağını oluşturan vergi oranlan ile vergi gelirleri arasındaki ilişkidir. Bu analizde vergi oranlarının belli bir orandan sonra vergi gelirlerini düşüreceği belirtilir. Vergi oranları optimalin üzerine çıktığı zamanlarda vergi gelirleri azalmaya baslar, çünkü insanlar çalışmak yerine vergisiz para kazanma yollarını ararlar. Vergi oranları artmaya başladığında esasen ekonomik faaliyetlerde rakamlarla ifade edildiği şekilde azalma olmaz sadece yüksek vergi oranları sebebiyle kayıtlı ekonomiden kayıt dışılığa kayış söz konusu olur. Bu durumda da kayıtlı ekonominin boyutu küçülür (Kıldiş, 2000).

\subsection{Vergilerin Kullanıldığı Alanlar}

Kaçakçılık faaliyetleri ile devletin uğramış olduğu vergi kaybı, devletten hizmet alamadığını düşünen bireyler için ikinci planda kalabilmektedir. Kaçakçılığın devlete vergi kaybına neden olabilmesi için, söz konusu kaçak malın taşındığı bölgede bir talep görmesi şarttır. Kaçak ürünün nihai tüketicisi, bu ürünü kullandığı için devletin vergi kaybına uğradığını düşünerek bu ürünü kullanmaktan vazgeçmesi, kaçak mala olan talebi azaltacaktır. Ancak, gerek bireyler, gerek maliyetini kısmak isteyen firmalar kaçak mala olan talebi canlı tutabilmektedirler. Söz konusu kişi veya firmalar burada, kaçak üründen elde edebilecekleri faydayı, vergi ile sağlayacakları fayda ile kıyaslayarak bu talebi sağlayabilirler.

Yapılan çalışmalar, toplanan vergilerin kullanım alanlarıyla, mükelleflerin vergiye yönelik tutumları arasında bir ilişki olduğunu göstermektedir. Buna göre, ödediği verginin toplumun ihtiyaç duyulan alanlarına harcandığına inanan mükellefler vergisini eksiksiz ve zamanında ödemektedirler. Diğer bir taraftan verginin kullanıldığı alanları onaylamayan ya da bekledikleri hizmetleri alamayan mükelleflerin vergiye karşı olumsuz bir tavır sergiledikleri görülmüştür (Şenyüz, 1995).

Vergi yönetiminden (devletten) memnuniyetsizlik derecesi de mükelleflerin gönüllü uyumu üzerinde etkili olmaktadır. Mükellefler ödedikleri verginin karşılı̆ında birtakım kamu hizmetlerinden yararlanırlarsa (verginin karşılığında hizmet alırlarsa) gönüllü uyum dereceleri ve dolayısıyla beyan edilen gelirleri daha da yükselecektir (Alm vd., 1992). Bunun gibi kaçakçılık faaliyetine konu olan ürünlere olan talep de, devletin bu ürünlerden elde edeceği vergi geliri ile kendilerine faydası olacak mal ve hizmet üretiminde bulunabileceği inancı ile azalabilmektedir.

\subsection{Vergi Ahlakı}

Genellikle vergi kaçakçılığı konusunda kullanılan vergi ahlakı kavramının, kaçakçılık faaliyetlerine konu olan ürünlerin kullanımı konusunda da önemli bir kavram olarak değerlendirildiği gözlemlenebilmektedir. Çünkü, kaçakçılığa konu olan ürünlere yönelik talepte de devlet vergi kaçakçılı̆ında olduğu gibi vergi kaybına uğrayabilmektedir.

Mükelleflerin vergiye yönelik tutumlarını etkileyen bireysel etmenlerden biri de mükellefin sahip olduğu vergi ahlakıdır. En genel haliyle vergi ahlakı mükelleflerin vergi kaçakçılığı ve vergi cezaları karşısında takındığı tavır olarak tanımlanabilir. Bu tanımda ahlak kavramının felsefi ya da teolojik bir kavram olarak değil, toplumun ortak olarak benimsediği erdemli davranışların sergilenmesi şeklinde kullanıldığı unutulmamalıdır (Schmölders, 1976).

Vergi mükellefleri ile oluşturulacak işbirliği ve güvene dayalı ortam, mükelleflerin vergi ahlakının güçlenmesine sebep olur. 1969 'da Strümpel tarafından İngiltere ve Almanya'da yapılan bir araştırmada, iki ülke mükellefleri arasındaki vergi ahlakının anlamlı derecede farklılık gösterdiği gözlenmiştir. Bu durumun nedenleri araştırıldığında ise, Almanya'daki vergi sisteminin daha katı ve yaptırımcı olduğu, İngiltere'deki vergi sisteminin ise daha katılımcı bir politika izlediği ortaya çıkmıştır. Dolayısıyla, vergi ahlakının, bireylerin politik karar alma sürecine yaygın ve etkin bir şekilde katılması ile doğru orantılı olduğu söylenebilir. Bu durumda mükellefler devletin kendilerine adaletli davrandığını hissederler ve ödedikleri vergiler ile kamu yatırımları arasında doğru orantı kurarlar. Bu aktif katılım aynı zamanda, mükelleflerin yasalar ve politikacılar üzerindeki kontrol kabiliyetlerini yükselteceğinden, memnuniyet derecelerini de artırır. Bu durumun vergiye gönüllü uyum üzerinde pozitif bir etki yaratacağı söylenebilir (Strumpel, 1969). Görüldüğü üzere vergi ahlakını olumlu yönde etkileyen etkenlerden en önemlisi makul oranlarda vergilendirme ve mükelleflerle katılımcı bir politika 
izlemekten geçmektedir. Vergilendirmede adalet ilkesinin uygulanmadığı, yüksek vergi oranlarının uygulandığı vergilendirme sistemlerinde vergi ahlakının kaçakçılık faaliyetlerinin önüne geçmede çok güçlü bir etmen olamayacağı görülebilmektedir

\subsection{Coğrafi Faktörler}

Ülkemizin yaklaşık $1000 \mathrm{~km}$. uzunluğunda olan doğu sınırlarının, genellikle zor coğrafi şartlara sahip olduğu görülebilmektedir. Yüksek dağlara, derin vadilere ve sarp kayalıklara sahip olan doğu bölgemizde sınır kontrolleri zor şartlar altında sağlanmaya çalışılmaktadır.

Doğu sınırımızın önemli kısmını oluşturan, yaklaşık $454 \mathrm{~km}$ uzunluğundaki Türkiye-iran sınırı, çoğu yerde yükseltisi 2500-3000 metreyi aşan dağlık alanlardan geçmektedir. Buradaki dağlar, Küçük Ağrı hariç, genellikle kütlevi ve birbirinden eşik ve vadilerle ayrılan sıradağlar şeklinde uzanmaktadır. Sınır bölgesinde yer alan en yüksek noktaya, kuzeyde 3896 m. ile Küçük Ağrı Dağı'nda ulaşııı. Sınııın hemen batı kenarında, sönmüş bir volkan olan K. Ağrı; kuzeyde Iğdır ile güneyde Doğubayazıt ovaları arasında yer alır. Doğubayazıt'ın güneyinde Tendürek Dağı'na kadar uzanan alanda Akyayla Dağı $(2503$ m) bulunur. 3533 m yüksekliğe sahip Tendürek Dağı 'nın doğusundan itibaren güneye doğru, kuzey-güney yönlü ve güneye doğru gittikçe yükseltisi artan dağ sıraları bulunur ve sınır, genellikle bu dağların su bölümü çizgilerini takip eder. Sınırın güneyinde, özellikle Kotur vadisinden İran, Irak ve Türkiye üçgenindeki Kandil Dağı'na kadar uzanan kısmı, son derece sarp ve dağılık arazilerden geçmektedir (Deniz ve Doğu, 2008).

Bu zor coğrafi şartlara rağmen, Türkiye'nin en fazla yasadışı geçişlere sahne olan sınırı, Türkiye- İran sınırıdır. Her yıl gerek mal kaçakçılarının gerekse yasadışı göçmenlerin büyük bir kısmının, ülkeye girişte bu sınırı kullandıkları bilinmektedir. Dolayısıyla kaçakçılar ve göçmenler, sınır geçişleri esnasında sınır boylarına döşenen mayın ve güvenlik kuvvetlerinin kurşunlarına hedef olma intimali yanında, ağır coğrafi şartlarla da mücadele etmek zorunda kalmaktadırlar. Özellikle kış ayları onlar için tam bir işkenceye dönüşebilmektedir. Çünkü yüksek dağıık alanlardan sınırı geçip uzun mesafeler boyunca yürümek zorunda kalmaları, kaçakçılar ve göçmenlerin kar fırtınasına yakalanarak yollarını kaybetmelerine, soğuktan donarak ölmelerine ve kurtlar tarafından parçalanarak hayatlarını kaybetmelerine neden olabilmektedir (Deniz, 2011 ).

Kaçakçıık faaliyetlerini yürüten söz konusu kişiler için, bu zor coğrafi şartlar barındırdığı tehlikelerin yanında fırsatlar da sunmaktadır. Zor coğrafi koşullardan oluşan uzun sınır bölgeleri, çok zor iklimsel şartlarla birleşince devlet açısından sınırların denetimi ve savunması da zorlaşmaktadır. Kaçakçılık faaliyetleri bu zor şartlardan her ne kadar olumsuz etkilense de, aynı şartların sağlamış olduğu denetim eksikliğinden de aynı ölçüde yararlanabilmektedir.

\subsection{Sosyo-Ekonomik Faktörler}

Sınır bölgesindeki doğal ortam koşulları dışında başka faktörlerinde kaçakçılık üzerinde etkisi bulunmaktadır. Özellikle sosyo-kültürel ve ekonomik yapının önemli etkisinin olduğu düşünülmektedir. Yani, eğitim seviyesinin düşük ve istihdam olanaklarııı sınırı olması, sınır bölgesinde insanların kaçakçıllğa yönelmesinde etkili olmaktadır. Özellikle bölgedeki geleneksel ekonomik yapıyı oluşturan tarım ve hayvancilığın sekteye uğraması ve ayrıca kaçakçılı̆ı̆ kolay para kazanma yolu olarak görülmesi bu durumda önemli rol oynamaktadır (Deniz, 2011 ).

Mükelleflerin eğitimli olması vergi ile ilgili yasaları ve verginin uzun vadeli faydalarını daha kolay anlayacaklarından gönüllü uyumu arttırabilir. Öte yandan, eğitimin artması ile birlikte yasalardaki açıklıkları fark eden mükellef bu açıklıklardan yararlanarak vergiden kaçınma yöntemlerini daha kolaylıkla uygulayabilir. Ancak, çalışmaların çoğunda, eğitim düzeyi ile vergiye gönüllü uyum arasında doğru orantı olduğu söylenebilir. Yani kişinin eğitim seviyesi artıkça vergiye gönüllü uyum oranının da artması beklenmektedir (Aktan, 2006:164).

Türkiye- İran sınırına komşu sınır köylerinde ve ilçelerinde göze çarpan en önemli husus, kız ve erkek öğrencilerinin okullaşma oranları arasında belirgin bir farkın ortaya çıkması ve genel olarak okuma yazma oranının düşük olmasıdır. Türkiye'de 2004 yılı verilerine göre okuma yazma oranı $\% 87$ iken bu oran buradaki sınır ilçelerinde \% 65'de kalmaktadır. En düşük okuma yazma oranı Başkale'de (\% 55), en yüksek okuma yazma 
oranı ise Aralık'ta (\% 81) görülmektedir. Başkale, Türkiye'deki ilçelerin okuma yazma oranlarına göre yapılan sırlamada 872 ilçe içerisinden 866, Aralık ilçesi ise 638.nci sırada yer almaktadır (DPT, 2004).

Türkiye-Iran sınırının Türkiye tarafında Türkçe ve Kürtçe, İran tarafında ise Türkçe Farsça ve Kürtçe en çok kullanılan dillerdir. Ayrıca, sınırın her iki tarafındaki sınır köylerinin kültürel yapı ve sosyal yaşantıları da büyük ölçüde birbirlerine benzerlik göstermektedir. Iletişim kolaylığıyla birlikte sınırın her iki tarafındaki halklar arasındaki yakın ilişkinin, sınır kaçakçııı̆ının yaygınlaşmasında etkili olduğu görülmektedir. Çünkü kaçakçılıkta akrabalık ilişkisi, onlar için önemli bir güven unsuru olmaktadır (Deniz, 2011).

\section{DOĞU VE GÜNEYDOĞU ANADOLU BÖLGELERINDE KAÇAKÇILIK FAALIYETLERI VE VERGI KAYBI}

Doğu ve Güneydoğu Anadolu bölgeleri kendine has şartları gereği günümüzde olduğu gibi geçmişte de kaçakçıık faaliyetlerine sahne olmuştur. Özellikle, tarihte farklı devletler arasında coğrafi şartlardan dolayı doğal sınırlar olarak bölge sınır kaçakçılığı yaygınlaşmışırı. Özellikle Türkiye-Iran arasındaki sınır göz önüne alındığında asırlardır bu sınırın küçük değişikliklere rağmen aynı kaldığı söylenebilmektedir. Dönem dönem her iki ülkenin ekonomik durumuna göre bu sınırın, kaçakçılık faaliyetlerine çift yönlü olarak sahne olduğu değerlendirilebilir.

Türkiye sınırlarına dair ilk çalışma Mehmed Hurşîd Paşa'nın Seyahâtnâme-î Hudud adlı esediridr. Osmanlı kendi devletinin sınırlarının modernist bir tavırla kaydının gerektiğini 1847'de idrak etmiş, bu işle Mehmed Hurşîd Paşa'yı görevlendirmiştir. Mehmed Hurşîd Paşa, 1850'ye dek şiddetlenerek artan Irak ve İran sınır çatışmalarının halli için, 1848-1952 arasında Osmanlı, İran ve gözlemci olarak katılan Rusya ve İngiltere Devletlerinin temsilcilerinden oluşmuş bir komisyonun, son raporlandırılması aşamasında Seyâhatnâme-î Hudud3 adlı eserini kaleme almıştır. Daha önceleri çeşitli uluslardan bazı seyyahların ve araştırmacıların da hikaye ettikleri anılar elbette mevcuttur. Ancak Mehmed Hurşîd Paşa'nın Seyâhatnâme'si, Erzurum Eyaleti'ne bağlı Bazeyid Sancağı'ndan Basra Körfezi, Basra, Bağdad, Musul, Şehrizor ve Van Eyaletleri'ne dek tüm Suriye, Iran ve Irak sınırını kapsamaktadır. Daha önemlisi; Hurşîd Paşa, sadece sınıı çizmekle kalmamış; tüm sosyal yapıları (aşiret düzenekleri, çatışma ve paylaşım ilişkileri, nüfus ve yapısal sorunlar, özel adetler, farklılık ve benzerlikler temelinde sosyal yapıları) kapsayan ayrıntılı hikayelere de yer vermiştir (Özgen, 2011).

Türkiye'nin sınırla ilgili kanunlarını yapanların ve kanunu uygulayanların gözünde ve sınılara dair çalışanlar için de; sınırlarımız daima etnik sorunla iç içe adlandırılmışır. Bir diğer deyişle, Türkiye'nin kürt meselesi, daima sınır ve sınır güvenliğine dair bir sorun olarak da tartışıımıştır. Bu konuda yapılmış çeşitli çalışmalarda; sınırdaki etnisiteyle ilgili üç farklı durum ayırtedilmektedir:

1) Sınır boyunca, kendi devletinden ve karşıdan aynı etnik bağların içinden olanlar;

2)içinde bulunduğu devletteki kadar karşıyla da aynı oranda farklılaşan bir etnik gruptan olanlar;

3)Kendi devletinin ulusal çoğunluğundan olup, karşıyla etnik bağları bulunmayanlar. Suriye ve Irak sınııındaki çeşitli etnik yapılarda birinci ve ikinci türden bağıtlar görülür. Öte yandan, Yunanistan ve Bulgaristan sınırlarımızda, sınırın ilk zamanlarında yerleştirilen mübadele göçerleri, zamanla daha iç bölgelere alınmış, buralara Türk soyu olduklarından şüphe edilmeyenlerin yerleştirilmesine dikkat edilmiştir (Özgen, 2011).

\subsection{Gıda Maddesi Kaçakçılığı}

Kaçakçılığa konu gıda maddelerinin başında, çay, bal, yaş sebze ve meyve, bazı bölgelerde un, şeker gibi gıda maddeleri gelmektedir. Daha çok giriş kaçakçılığı şeklinde işlenmektedir ( Çöğgün, 2012).

Gıda kaçakçılığına yönelik operasyonlarda 2012 yılında 613.145 kg, 2013 yılında ise \% 303'lük artış ile 2.472.186 kg gıda ürünü ele geçirilmiştir. Ele geçirilen gıdaların ağırıkı olarak ceviz, badem, kırmızı et, bal ve şeker gibi ürünler olduğu görülmektedir. İran, Irak, Suriye, Bulgaristan ve Gürcistan'dan temin edilen gıda ürünlerinin yolcu ve yük taşımacılığında kullanılan araçlar vasıtasıyla ülkemize kaçak olarak girişi gerçekleştirilmektedir (KOM, 2013). 
Canlı Hayvan Kaçakçılığı olarak ise, genellikle küçükbaş hayvan (koyun) kaçakçılığı söz konusu olmakla beraber, az da olsa sığır ve deve gibi büyük baş hayvanlar da sınırdan kaçak olarak geçirilmektedir. Ekonomik dalgalanmalar ve ülkemiz ile komşu ülke para birimi arasındaki değer eşitliği, kaçakçılığın yönünü etkilemektedir. Sınırlarımızdan kaçak olarak giren hayvanların yurt içine sevklerinin ve pazarlanmasının engellenmesi ile ilgili olarak 3285 sayılı "Hayvan Sağlığı ve Zabıtası Kanunu" cezai hükümler getirmiştir. Et ve diğer hayvan ürünlerinin kaçak olarak ülkeye girmesi de bu kaçakçılık bağlığı altında ele alınmaktadır ( Çöğgün, 2012).

\subsubsection{Gıda Maddesi Kaçakçıı̆ı̆ının Neden Olduğu Vergi Kaybı}

Kaçakçılık faaliyetlerine konu olan ürünlerin ne kadarlık vergi kaybına neden olduğu tam olarak bilinememektedir. Doğası gereği resmi kayıtlardan ve resmiyetten uzak gerçekleştirilen kaçakçıık faaliyetlerinin sebep olduğu vergi kaybı ancak bir takım verilere dayanılarak tahmin edilebilmektedir.

Türkiye Ziraatçiler Birliği tarafından yapılan bir çalışmaya (2011) göre; kaçak gıda ve tarım ürünleri girişi, 10 milyar dolar gibi bir değere ulaşarak neredeyse resmi ithalat miktarına yaklaşıyor. Bu hesaplamalara göre;

- Kaçakçılığı için İran ve Irak'a günü birlik turların bile düzenlendiği şekerde, yıllık kaçak sokulan tutar 500 bin ton civarında. Bu oran Türkiye'de yıllık tüketimin yaklaşık beşte birine denk geliyor. Kaçak şekerin ekonomiye maliyeti ise 750 milyon dolar civarında,

- Özellikle üreticiye en büyük zararı olan ve yaygın olarak Doğu ve Güneydoğu Anadolu Bölgesi'nde tüketilen çayın kaçak yollardan Türkiye'ye giriş miktarı ise 60 bin ton civarında. Bunun önemli miktarı İran ve Suriye'den ülkemize giriyor. Ekonomiye maliyeti 75 milyon dolar civarında,

- Türkiye'ye İran, Irak ve Suriye üzerinden her yıl, büyük bir kısmı da küçükbaş olmak üzere 500 bin civarında canlı hayvan kaçak yollardan sokuluyor. Kaçak canlı hayvanın yıllık ekonomik zararı 750 milyon dolar civarında olmakla beraber bir diğer kaçak giriş yapan ürün de karkas et. Kaçak et ülkemize özellikle İran üzerinden giriyor. İstanbul'da tüketilen etin yüzde 40’ kayıt dışı. Bu rakam, Türkiye genelinde tüketilen etin de üçte birine denk düşüyor. Kaçak etin yıllık değeri de 5 milyar dolar civarında,

- Sınır ticareti adı altında özellikle Gürbulak Sınır Kapısından ülkemize sokulup tüm yurda dağııılan başlıca kivi, muz, kavun, karpuz, ananas ve mango kaçakçılı̆ı̆ın yıllık ekonomik değeri 500 milyon dolar civarında,

- Tüm bunların yanında her türlü konserveler, salam, sosis gibi hazır et ürünleri, sos, mayonez, ketçap gibi gıda katkıları, kek unu, hazır çorba, biber tozu ve özellikle Ortadoğu ülkeleri üzerinden gelen pirinç ve bakliyat ürünlerinin kaçakçılığı artış gösteriyor. Bunların toplamının ekonomik değerinin 1 milyar dolar civarında oluğu tahmin ediliyor.

Türkiye Ziraatçiler Birliğgi'nin yaptığı çalışmaya dayanan verilere göre, Türkiye’ye giren kaçak gıda maddelerinin piyasa değerinin 7 milyar TI üzerinde olduğu görülebilmektedir. Bu durumda devletin yıllık vergi kaybının ise 1 milyar TL olarak gerçekleştiği tahmin edilmektedir.

\subsection{Ticari Eşya Ve Malzeme Kaçakçılığı}

Toplum sağlığına zarar veren, vergi kaybına neden olan, kayıt dışı ekonomiyi tetikleyen ve istihdamın azalmasına yol açan emtia (eşya) kaçakçıı̆ı ise geniş bir yelpazeye sahiptir. Elektronik eşya, gıda maddeleri, kişisel kullanım malzemeleri, tekstil ve ev eşyaları gibi muhtelif ürünler emtia kaçakçıllğı çerçevesinde değerlendirilmektedir. Emtia kaçakçılığı ile mücadele kapsamında 2013 yılında 2.472 .186 kg muhtelif gıda, 397.490 adet cep telefonu, 9.260.002 adet ilaç (hap) ve 5.529 .060 adet muhtelif eşya ele geçirilmiştir. 2012 yılına kıyasla 2013 yılında, cep telefonu sayısında \% 64, muhtelif eşya miktarında \% 13, muhtelif gıda yakalamalarında \% 303 ve ilaç (hap) yakalamalarında ise \% 352'lik bir artış olduğu görülmektedir (KOM, 2013).

Emtia kaçakçıllğı, ithal izni olan firmaların ülkemize ticarî amaçla getirdikleri eşyaların yasal belgelerinden yararlanarak yasadışı yollardan ülkemize yanında başka mallarda getirilmekte veya 1615 sayılı "Gümrük Kanunun" zati eşyaların vergi muafiyetinden yararlanmak suretiyle malların ülkemize sokulması şeklinde karşımıza çıkmaktadır. Tütün, tütün mamulleri ve alkollü içkiler dışında elektronik cihazlar, ev, giyim, süs 
eşyaları, gıda maddeleri, sağlık malzemeleri vb. eşyaların gümrük işlemine tabi tutulmadan ülkemize sokulması olarak tanımlanabilir ( Çöğgün, 2012).

\subsubsection{Ticari Eşya Ve Malzeme Kaçakçılığının Neden Olduğu Vergi Kaybı}

Ankara Ticaret Odası'nın yayımladığı bir araştırmaya (2006) göre, son 10 yılda 40 milyon 435 bin 552 adet cep telefonu ithal edildiği, bu ithalat için de 5 milyar 551 milyon dolar para harcandığı görülmektedir. Ancak Telekomünikasyon Kurumu'nun verilerine göre ise, son 10 yılda Türkiye'ye 70 milyon cep telefonu girdiği belirtilmektedir. Bu miktarın parasal değerinin ise 15 milyar dolar civarında olduğu tahmin edilmektedir. Iki kurumun kayıtları arasındaki fark, Türkiye'ye kaçak giren cep telefonu sayısını gösterebilmektedir. Bir başka ifadeyle, kaçak yollarla Türkiye'ye sokulan cep telefonu sayısının 29,6 milyon olduğu, cep telefonu cihazı kolayca paraya dönüştürülebildiği için çok sayıda suç örgütü cep telefonu kaçakçılığına yöneldiği değerlendirilmektedir. Türk Telekomünikasyon Kurumu'na göre ise kaçak cep telefonu sayısı 12 bin civarında olduğu, bu yüzden devletin uğradığı gelir kaybı ise 1 milyar dolar civarında olduğu tahmin edilmektedir.

\subsection{Tütün Ve Alkollü İçecek Kaçakçılığı}

Vergi gelirlerini azaltan, toplum sağlığını olumsuz yönde etkileyen, terör ve organize suç örgütleri için önemli bir finans kaynağı teşkil eden tütün mamulleri kaçakçılığı ile mücadele kapsamında 2013 yılında 20.779 olayda 30.860 şüpheli şahıs yakalanmış, 108.243 .473 paket kaçak sigara ele geçirilmiştir. 2012 yılında ele geçirilen 99.100.151 paket ile kıyaslama yapıldığında \%9'luk bir artışın olduğu görülmektedir (KOM, 2013).

Tütün ve Tütün Mamulleri Kaçakçılığı, Genel olarak sigara, puro, kıyılmış tütün bu başlık altında ele alınmaktadır. Yöntemleri;

- Başka bir mal adı altında ithal edilmesi veya transite tabi olmasına rağmen çıkış yapılmayarak yurtta bırakılması,

- "Free Shop"lara aktarılan veya aktarıldı gösterilen sigaraların yurtdışına çıkan yolcuların adına fiş kesilerek iç piyasaya sürülmesi,

- Serbest Bölgelerden gelen beyan fazlası sigaraların kaçak olarak yurda sokulması

- İthal yükü getiren TIR'ların içine gizlenmesi,

- Yolculara tanınan muafiyetin başkaları tarafından alınıp iç piyasaya sürülmesi yollarıyla tütün ve tütün mamulleri kaçakçılığı yapılmaktadır.

Alkollü İçki Kaçakçılığı ise Tütün ve tütün mamulleri kaçakçılığında kullanılan yöntemler genellikle alkollü içkiler kaçakçılığında da kullanılmaktadır ( Çöğgün, 2012).

Son yıllarda Türkiye genelinde ele geçirilen kaçak sigaraların \%80’e yakın kısmının Doğu ve Güneydoğu Bölgesi sınırlarından ülkemize getirildiği göz önüne alındığında, terör örgütünün kazancının ne denli büyük olduğu ortaya çıkmaktadır. Kaçak tütün ve tütün mamulleri genellikle Doğu ve Güneydoğu Bölgesi illerimiz üzerinden sırtçılık yöntemiyle getirilmektedir. Ayrıca son dönemlerde transit rejimi kapsamında sevkiyat yapılan TIR'larda sahte mühür kullanılması ya da mühür halatlarının kırılması suretiyle kaçak sigaraların yasal yüklerin arasına gizlenmesi yöntemi kullanılarak da ülkemize getirildiği tespit edilmiştir (KOM, 2013).

Alkollü içki kaçakçılığı ve sahteciliği ile mücadele kapsamında sahte alkollü içki imalathanesi tespitine büyük önem verilmiş ve bir önceki yıla göre bu alandaki tespitler \% 50 oranında artmıştır. Aşağıda verilen Tablo 1'den de izlenebileceği üzere imalathanelere karşı yürütülen başarılı çalışmalar sayesinde 2013 yılında 135.191 şişe alkollü içki ele geçirilmiş ve bir önceki yıla göre alkollü içki yakalamalarında \% $45^{\prime}$ lik bir düşüş meydana gelmiştir (KOM, 2013).

Tablo 1: Kaçak Sigara Yakalama Miktarları (Paket)

\begin{tabular}{|c|c|c|c|c|}
\hline $\mathbf{2 0 0 9}$ & $\mathbf{2 0 1 0}$ & $\mathbf{2 0 1 1}$ & $\mathbf{2 0 1 2}$ & $\mathbf{2 0 1 3}$ \\
\hline 10.149 .605 & 43.545 .267 & 69.730 .125 & 99.100 .151 & 108.243 .473 \\
\hline
\end{tabular}


Kaynak: KOM, 2013 Raporu

\subsubsection{Tütün Ve Alkollü İçecek Kaçakçılığının Neden Olduğu Vergi Kaybı}

Türkiye Ziraatçiler Birliği tarafından yapılan aynı çalışmaya (2011) göre; Her yıl Irak'ın Dohuk ve Süleymaniye kentlerindeki fabrikalarda üretilen sigaraların 25 bin tonu kaçak yollardan Türkiye piyasasına sokulmakta ve sadece bu kaçakçılıktan dolayı ülkemizin vergi kaybının yıllık 2,5 milyar dolar olduğu tahmin edilmektedir.

Memurlar.net'in Anadolu Ajansı'na dayandırdığı haberine (2011), göre, Türkiye Esnaf ve Sanatkârları Konfederasyonu (TESK) Genel Başkanı Bendevi Palandöken 10 numara yağ, kaçak tütün ve alkollü içeceklerin oluşturduğu vergi kaybının yıllık 4 milyar $t$ civarında olduğunu belirtmiştir. Ülkemizde yakalanan kaçak alkollü içki miktarlarına dair bilgilere aşağıda Tablo 2'de yer verilmiştir.

Tablo 2: Kaçak Alkollü İçki Yakalama Miktarları (Şişe)

\begin{tabular}{|c|c|c|c|c|}
\hline 2009 & 2010 & 2011 & 2012 & 2013 \\
\hline 10.149 .605 & 43.545 .267 & 69.730 .125 & 99.100 .151 & 108.243 .473 \\
\hline
\end{tabular}

Kaynak: KOM, 2013 Raporu

\subsection{Akaryakıt Kaçakçılığı}

Akaryakıt kaçakçılığının diğer kaçakçılık faaliyetleri arasında Türkiye için ayrı bir önemi bulunmaktadır. Zira özel tüketim vergileri toplamının \%51'lik kısmı akaryakıt ürünlerinden elde edilmektedir. Türkiye, ucuz akaryakıt satışının yapıldığı üretici ülkelere komşu olması ve komşu ülkeler ile ülkemiz arasındaki fiyat farkı nedeniyle akaryakıt kaçakçılığına maruz kalmaktadır. Akaryakıt kaçakçılığıyla mücadele kapsamında 2013 yılında 3.691 olayda 6.082 şüpheli yakalanmış, 17.422 .557 litre kaçak akaryakıt ele geçirilmiştir. 16.411 .404 litre kaçak akaryakıt ele geçirilen 2012 yılı ile kıyaslandığında 2013 yılında yaklaşık \%6'lık bir artış olduğu görülmektedir (KOM, 2013).

Aşağıda verilen Tablo 3'ten de görülebileceği üzere ülkemizde son yıllarda akaryakıt kaçakçılığı miktarlarında sürekli artış gözlenmektedir.

Tablo 3: Yıllara Göre Ele Geçirilen Kaçak Akaryakıt Türleri ve Miktarları (lt)

\begin{tabular}{|c|c|c|c|c|c|}
\hline Akaryakıt Türü & 2009 & 2010 & 2011 & 2012 & 2013 \\
\hline Motorin & 7.929.749 & 4.251 .300 & 4.928 .451 & 5.783 .696 & 7.924 .632 \\
\hline Benzin & 84.380 & 123.155 & 65.910 & 66.988 & 27.427 \\
\hline Fuel-Oil & 4.636.691 & 111.518 & 236.021 & 1.146 .221 & 82.898 \\
\hline Solvent & 93.432 & 374.471 & 487.155 & 924.393 & 60.876 \\
\hline Bio-Dizel & 8.000 & 39.760 & 460 & 30.916 & 15.000 \\
\hline Katkılı Akaryakt & 1.293 .903 & 1.999 .776 & 2.727 .591 & 4.525 .607 & 3.933 .143 \\
\hline Ham Petrol & 558 & 4.778 & 93.343 & 357.074 & 283.923 \\
\hline Madeni Yağ & 325.047 & 745.250 & 1.597 .615 & 1.800 .387 & 2.128 .417 \\
\hline Lpg & 10.444 & --- & --- & 57.855 & 247.262 \\
\hline Gazyağı & 4.000 & 2.830 & 102.713 & 326.217 & 112.320 \\
\hline Jet Yakıtı & 2.000 & $-\overline{--}$ & 98.154 & 1.392 .050 & 2.606 .659 \\
\hline
\end{tabular}




\begin{tabular}{|l|l|l|l|l|l|}
\hline Toplam & 14.388 .204 & 7.652 .838 & 10.337 .413 & 16.411 .404 & 17.422 .557 \\
\hline
\end{tabular}

Kaynak: KOM, 2013 Raporu

Yörede gerek tarım, gerekse sanayi sektöründe kayda değer bir üretim faaliyeti olmaması ve dolayısıyla fazla ulaşım kapasitesi olmamasına rağmen, yöredeki kamyon sayısındaki artışlar dikkat çekicidir. Örneğin Van Emniyet Müdürlüğü verilerine göre 2004 yılında Van'da 10303 adet kamyon ve kamyonet bulunurken, bu sayı iki yıl sonra (2006'da) \% 50 oranında artarak 15786'ya yükselmiştir. Kamyon ve kamyonet sayısındaki bu artışın kaçak akaryakıt taşımacılığıyla doğrudan ilgisi olduğu değerlendirilmektedir. Çünkü çok sayıda kamyon ve deposu büyütülen taksilerin, sınır köyleri ile bölgedeki kentler arasında boş gidip geldiği ve bu araçların kaçak akaryakıt taşıdığı yöredeki bütün kesimlerce bilinmektedir. Bu durum, bölgedeki karayollarının trafik yoğunluğuna da yansımış durumdadır. Normalde bölgedeki karayolları içinde en az trafik yoğunluğuna sahip olması beklenen Van-Başkale arasındaki yol, akaryakıt kaçakçılığı nedeniyle bölgenin en yoğun trafik hacmine sahip yollarından birisi haline gelmiştir (Deniz, 2011).

\subsubsection{Akaryakıt Kaçakçılığının Neden Olduğu Vergi Kaybı}

2005 yılındaki bir TBMM araştırma komisyonunun raporunda (TBMM, 2005: 201) sadece İran sınırından Türkiye'ye katır sırtında geçirilen kaçak akaryakıt miktarı 150 bin ton olduğu ifade edilmektedir. Aynı komisyonun raporunda Türkiye'deki yıllık kaçak akaryakıt miktarının 4,5 milyon ton olduğu tahmin edilmektedir. Dolayısıyla güvenlik güçleri tarafından yakalanan akaryakıt miktarının, tahmin edilen gerçek akaryakıt kaçakçılığının çok az bir kısmına karşılık geldiği ve yakalanan akaryakıtın en az 20 katının yakalanmadan iç piyasaya sürüldüğü değerlendirilmektedir.

\section{SONUÇ}

Kaçakçılık suçlarının günümüzde, devletlerin en önemli sorunlarından biri haline geldiği gözlemlenmektedir. Bu sorun dünyanın farklı bölgelerinde farklı devletler için farklı boyutlarda kendini göstermektedir. Özellikle ekonomik büyümesini tamamlayamamış, az gelişmiş veya gelişmekte olan ülkelerde kaçakçılık suçları daha fazla hissedilmektedir. Kaçakçılık faaliyetleri ile birlikte devletler vergi kaybına uğramakta ve ekonomileri zarar görmektedir. Kamu harcamaları için gerekli ihtiyacın büyük bir kısmını karşılayan vergi gelirleri, böylelikle azalmakta ve kamu hizmetlerinin aksamasına veya finansmanında sorun yaşanmasına neden olmaktadır.

Devletlerin kaçakçılıkla mücadelelerini sürdürmelerine ve kaçakçılık faaliyetlerinin riskli şartlarda gerçekleşmesine rağmen, kaçakçııı suçlarının azalmadığı görülmektedir. Kaçakçılık suçlarının azalma eğilimi göstermemesinin nedenleri arasında, vergi yükünün ve vergi oranlarının fazla olması öne çıkmaktadır. Devletlerin vergileri kullandığı alanlar ve toplumun vergi ahlakı erozyonu da kaçakçılığı besleyebilmektedir. Bunun yanında kaçakçılık faaliyetlerinin yürütüldüğü bölge coğrafyası, kaçakçılık için elverişli ise kaçakçılık faaliyetleri için özendirici olabilmektedir. Ayrıca, bölgenin sosyo-ekonomik şartları, eğitim, istihdam ve gelir durumu da kaçakçılık faaliyetleri üzerinde bir etken olabilmektedir.

Ülkemizde ise Doğu ve Güneydoğu Anadolu bölgeleri, özel konumu ve doğal şartları açısından kaçakçılık faaliyetlerinin sık görüldüğü bölgelerimizdir. Özellikle kaçaklığa konu olan ürünlerin, geldiği ülke ile ülkemiz arasında fiyat farkının fazla olması kaçakçılık için esas motivasyon kaynağını oluşturmaktadır. Özellikle akaryakıt kaçakçılığı, tütün ve alkollü içecek kaçakçılığı yüksek kar oranı imkanı ile en önemli kaçak ürünler arasında yer almaktadır. Bu ürünlere ticari eşya kaçakçılığı ve gıda ürünleri kaçakçılığı da eşlik etmektedir. Ülkeye sokulan kaçak ürünlerin ne kadarlık bir piyasa değerine sahip olduğu net olarak bilinememektedir. Bununla birlikte yapılan çalışmalara göre, kaçakçılık faaliyetleri nedeniyle devletin uğramış olduğu vergi kaybının 15-20 milyar dolar arası olduğu tahmin edilmektedir. 


\section{KAYNAKLAR}

Aktan, C, C. (2006). Vergileme Ekonomisi ve Vergileme Psikolojisi, Vergi Dışı Piyasa Ekonomisi, Ankara: Seçkin Yayınları, $189-164$.

Alm, J., Jackson, B., McKee, M. (1992). Institutional Uncertainty and Taxpayer Compliance, American Economic Review, 82, 4.

Andreoni, J, Erard, B. \& Feinstein, J., (1998). Tax Compliance, Journal of Economic Literature, 36, 818 - 860.

Çiçek, H. (2006). Psikolojik ve Sosyal Yönden Yükümlülerin Vergiye Karşı Tutum ve Tepkileri, İstanbul: İstanbul Serbest Muhasebeci ve Mali Müşavirler Odası Yayınları, 165-189.

Çöğgün, M. (2012). Şırnak - Uludere Kaçakçılıkla Mücadele, İdarecinin Sesi Dergisi, Ocak-Şubat, 33-38.

Deniz, 0. (2011) Türkiye-İran Sınırında Akaryakıt Kaçakçıı̆ı̆ Ve Etkileri. Polis Akademisi Yayınları Terörizm ve Sınıraşan Suçlar Serisi: 4 Ankara, Haziran 2011.

Deniz, O., ve Doğu, A. F. (2008). Türkiye- İran Sınırı: Sınırın Coğrafi Durumu ve Sınır Köylerimizin Sosyo-Ekonomik Yapıları, Doğu Coğrafya Dergisi, 19, s.49-71.

DPT. (2004). İlçelerin Sosyo-Ekonomik Gelişmişlik Sıralaması Araştırması, Ankara.

EKER, A. (2001). Kamu Maliyesi, İzmir: Anadolu Yayıncılık,, s.119.

KILDiş, Y. (2000). Kayıt Dısı Ekonominin Ulusal-Uluslararası Boyutu ve Çözüm önerileri, DEÜ Sosyal Bilimler Enstitüsü Dergisi, Cilt 2. Sayı:2, s.3-20.

http://www.kom.pol.tr/SiteAssets/Sayfalar/Raporlar/2013\%20KOM\%20Raporu-T\%C3\%BCrk\%C3\%A7e.pdf

http://www.memurlar.net/haber/202610/

Özgen, N. (2011). Sınırda Kaçakçı Olmanın Antropolojik Tarihi. NTV Tarih Aralık, 2011.

Schmölders, G. (1970). Survey Research in Public Finance: A Behavioral Approach to Fiscal Theory. Public Finance, 25, 300-306.

Şenyüz, D. (1995). Vergilendirmede Yükümlü Psikolojisi, Bursa:

TBMM. (2005). Türkiye'de Akaryakıt Kaçakçılığının Ekonomiye, İnsan ve Çevreye Verdiği Zararlar. Meclis Araştırma Komisyonu Raporu (16. 06. 2005 Tarih ve 10/238-215 Numaralı), Ankara. 